\title{
Developing Human Resource Productivity through Organizational Justice
}

\author{
Mohammad Reza Sadeghi (Corresponding Author) \\ M.S. of Public Administration, University of Tehran, Tehran, Iran \\ Tel: +98-912-750-9149Ｅ-mail: Rsadeqi@ut.ac.ir
}

Seyyed Mohammad Mahdi Musavi

PhD Candidate of Organizational Behavior, University of Tehran, Qom Campus, Iran

Saied Samiie

PhD Candidate of Futures Study, University of Tehran, Tehran, Iran

\begin{abstract}
Amirhesam Behrooz
M.S. Candidate of Executive Management of Business Administration, University of Tehran, Tehran, Iran
\end{abstract}

Received: May 15, 2013 Accepted: June 14, 2013 DOI: 10.5296/jpag.v3i2.3575

\begin{abstract}
Productivity, the methods to measure it and identifying affecting factors on it are yet considered as the main issues of knowledge management and organization. Based on present study, the relationship between organizational justice and human resource productivity is studied. The findings of correlation test show a significant relationship between organizational justice and human resource productivity correlation coefficient $(0.584)$. In the meantime, the findings of regression analysis indicate that it is a linear relationship. Ultimately, a multiple regression test on variables show that distributive justice has the highest impact on human resource productivity and one unit change in this variable would result into 0.425 units change in human resource productivity and one unit change in interactional justice would result into 0.336 units change in human resource productivity.
\end{abstract}

Keywords: Organizational Justice, Distributive justice, Procedural Justice, Interactional Justice, Human Resource Productivity 


\section{Introduction and Problem Description}

In present changing conditions, organizations have to pay sufficient attention to their human resources in order to achieve more efficiency and effectiveness and finally to achieve determined aims. It means that organizations believe that the most important way to enhance organizational productivity is to improve their human resource productivity. The report by Asian Productivity Organization (APO) in 2009 indicates that human resource productivity index in Iran is too lower than other countries in Center and East Asia and the average growth of human resource productivity was $2.03 \%$ between 2000 and 2006 which shows that Iran has $9^{\text {th }}$ rank among 14 members of APO. Studies indicate that employees and their productivity are sensitive and react to conceived equality of decision to allot the resources like the level of payments, procedures upon which distribution decisions are made and equality in behavior with individuals during the implementation of procedures (Colquitt et al., 2006, 108).

On this basis, the question to which present study attempts to answer is that what is the relationship between employees' conception on the amount of organizational justice and human resources productivity and how is the impact of employees' conception regarding organizational justice on human resources productivity? On the other hand, Crapanzano (2001) believes that the main question is justice literature is that how employees assess the justice, why they act in this manner and what they study to evaluate the justice (Barclay, 2005, 744).

In present paper, organizational justice is considered as the independent variable and human resource productivity as the dependent one. The main aim of the research is to study the amount of employees' conceived justice in the organization as well as its different aspects including distributive justice, procedural justice and interactional justice as well as its impacts on human resource productivity.

\section{A review of theoretical basics}

Research theoretical basics address to organizational justice and human resource productivity.

\subsection{Organizational justice}

During past decade, organizational justice is highly respected and a broad range of studies has addressed it (Eberlin \& Tatum, 2008, 311). Increasingly interest in this issue in management and organization fields has led into paramount studies on organizational justice (Ambrose et al., 2007, 21). Justice is a main issue in conceiving and recognizing organizational behavior and refers to fair and ethical behavior of people in an organization (Bos, 2002, 866). Within past 25 years, studying justice in different fields including economy, psychology, laws and organizational sciences is highly respected (Dulebohn et al., 2009, 141). Major part of such respect to justice is due to the importance of working outcomes which relate to employees' conception on fairness and justice in organizational ambiences (Johnson et al., 2006, 175). For instance, the outcomes of conceived fairness and justice include job satisfaction, satisfaction of supervisor, organizational commitment, employees' efficiency, citizenship behaviors and job performance (Olkkonen \& lipponen, 2006, 204). The aspects of organizational justice are used widely as the descriptive variables of organizational studies. 


\section{$\triangle$ Macrothink}

Kremer clarifies organizational justice as the dominated theme in organizational life (Abu Elanain, 2010, 6).

Organizational justice refers to employees' attitude on the fact that whether the organization treats them fairly. Particularly, organizational justice focuses on behaviors resulted from justicelinjustice conceptions by employees and the relationship between such conceptions and other variables in workplaces. There is a general concurrence that organizational justice involves at least two factors namely distributive justice and procedural justice (Hassan \& Hashim, 2011, 83).

There are broad studies on organizational justice and paramount empirical findings are supporting them. For instance, empirical works show a positive relationship between the conception of fairness and employees' citizenship behavior. Fair behaviors make future events more controllable and predictable through decreasing distrust in daily working life. Finally, fair behavior indicates to follow ethical and spiritual standards by organizational officials (Colquitt et al., 2006, 110). Likewise, there is a remarkable respect to study justice conception predictors in the hope of fairness and justice improvement in organizations. Generally, there is concurrence that working results, the procedures which determine such results and the possibility of providing statements and explanations as well as the respect achieved through others all impact significantly on the content and amount of conceived justice and fairness (Johnson et al., 2006, 175).

\subsection{The concept of organizational justice}

Organizational justice is very complicated issue with different and deceiving terms and meanings (Eberline \& Tatum, 2005, 1041). In describing the special importance of justice in organization, Greenberg (1996) invented organizational justice. It is a term refers to individuals' conceived fairness (Hoy \& Tarter, 2004, 250). Schmink et al (1997) stated that the main concept of organizational justice is fairness which impacts on individuals' judgment regarding false and true items (McCain et al., 995). Fair behavior is what employees expect to receive in the extent of their allocated time and energy to organization (Eberlin and Tatum, $2005,1041)$.

\subsection{The aspects of organizational justice}

There are some categories for organizational justice. However, the category provided by Greenberg enjoys stronger support (Eberlin \& Tatum, 2008, 311). According to Greenberg (1980), organizational justice consists of three different aspects: distributive justice, procedural justice and interactional justice (McDowall \& Fletcher, 2004, 10).

\subsubsection{Distributive justice}

Distributive justice relates to the conceived fairness of outcomes (Jafari et al., 2011, 1696) and refers to organizational payments like wage and promotion (Wang et al., 2010, 661). Distributive justice refers to the relationship between encourage and punishment with performance (Nirmala \& Akhilesh, 2006, 138). Distributive justice approach relates to structural aspects. Structural aspects are laws and environment of decision making process 
(Yilmaz \& Tasdan, 2009, 113). This attitude roots in Adams' equity theory (Abu Elanian, 2010, 7). According to equity theory, individuals compare their data from the outcome achieved from a relationship to other data. If the ratios are equal, the person feels distributive justice. If the ratios are not equal, the person feels injustice feeling (Jawahar, 2002, 813). By this theory, employees amend the quality and quantity of their job to keep the justice. When employees feel justice in the organization, there is less possible to look for balancing their outputs and inputs through acquiring personal interests. Besides, when employees feel that they are treated fairly, they will be more interested to sacrifice their short term personal goals for group or organization (McCain et al., 2010, 997). The rationality of distributive justice is expressed clearly and is the increase in contributors' satisfaction when it is believed that decision making in conflicts is fair and desired (Nabatchi et al., 2007, 150).

\subsubsection{Procedural justice}

Procedural justice relates to individual's understanding of processes that determine fair payments (Till \& Karren, 2011, 45). Procedures are considered fair when they are implemented without any conflict, without personal interests, based on precise and correct information, with the chance of amending the decision, by respecting to the interests of all interested partners and by following ethical standards (Jawahar, 2002, 813).

Conducted studies show that the direct impact of distributive justice on individuals' justice in workplace is influenced by procedural justice. In fact, there are similar evidences which show that the impact of procedural justice is stronger when receivables are undesired while desired receivables may attract individuals' satisfaction. Undesired receivables have proved more need to explanation and people's interest will be focused more on utilized procedures. By undesired receivables, procedural justice would impact more on individuals' reaction to decisions (Cremer, 2005, 5). For employees, procedural justice is a basis for their commitment. Procedural justice impacts on individuals' understandings on the fairness about the increases in salaries, promotions, organizational commitment and job satisfaction (Jafari et al., 2011, 1697). Distributive justice suggests that satisfaction is a function of deliverables (decision content) while procedural justice suggests that satisfaction is a function of process (passed steps for decision making) (Nabatchi et al., 2007, 150). Procedural justice is enhanced when decision making processes follow special laws. For instance, procedures should use right information, should be proportionate to people and time, should be neutral, should suggest mechanisms for amendment, should introduce the concerns of main groups and should follow dominated ethical standards (Zapata-Phelan et al., 2009, 94).

\subsubsection{Interactional justice}

Interactional justice is defined as an interactional quality conceived by someone in the process of approving organizational procedures (Jafari et al., 2011, 1696) and is related to human aspect of organizational activities (Yilmaz and Tasdan, 2009, 114). In fact, conceived interactional justice depends on employees' reaction to the behavior of their supervisors directly rendered in official procedures (McCain et al., 2010, 995). Bies and Moag (1986) were the first authors who suggested that interactional justice is a separated construct which relates to authenticity, trust, respect and courtesy (McDowall \& Fletcher, 2004, 10). 


\section{Macrothink}

Greenberg (1993) believes that interactional justice should be divided into two separated components: information justice and interpersonal justice (Till \& Karren, 2011, 46). Although both information justice and interpersonal justice enjoy a remarkable envelopment, researches indicate that they impact on justice understanding differently and they should be considered separately (Nabatchi et al., 2007, 151). Although procedural justice and interactional justice are considered as distinguished and separated constructs, procedural justice involves fairness and equality in official organizational structures and procedures to which approving such procedures is covered by interactional justice. Therefore, although official procedures may be considered as fair in an organization, interactional justice may be considered as negligible manager by a who is responsible for them (Johnson et al., 2006, 178).

\section{Productivity}

Productivity is a forever dynamic term which is always exposed by evolution and change (Sharifzadeh and Mohammdi Moghdam, 2009) and a concept understood mistakenly and is the result of varied definitions provided within three centuries. Below table depicts the trend of productivity concepts and definitions briefly.

Table 1: major productivity concepts and definitions during historical evolution (Layeghi, 2011)

\begin{tabular}{|c|c|c|}
\hline Institute/person & Year & Description \\
\hline $\begin{array}{l}\text { Quneensny }-18^{\text {th }} \\
\text { century }\end{array}$ & 1766 & The initial emergence of productivity \\
\hline Litreh -19 century & 1883 & Balanced manufacturing \\
\hline Erley $-20^{\text {th }}$ century & 1900 & $\begin{array}{l}\text { The relationship between outcome and used facilities to } \\
\text { manufacture a certain amount of outcome }\end{array}$ \\
\hline $\begin{array}{l}\text { Economic Cooperation } \\
\text { Organization }\end{array}$ & 1950 & $\begin{array}{l}\text { Outcome quotient (production or deliverable) to a } \\
\text { production factor }\end{array}$ \\
\hline Domile & 1955 & Changes in the amount of products due to used resources \\
\hline Fabrikent & 1962 & The ratio of output and input \\
\hline Kendrick and Cremer & 1965 & $\begin{array}{l}\text { Performance and functional definitions for a unique (or } \\
\text { single) factor productivity as well as collective } \\
\text { productivity }\end{array}$ \\
\hline Sietgel & 1976 & Total output to input ratios \\
\hline
\end{tabular}




\begin{tabular}{|l|l|l|}
\hline Somanth & 1979 & $\begin{array}{l}\text { Total productivity of factors to tangible output to tangible } \\
\text { inputs }\end{array}$ \\
\hline Kendrick and Cremer & 1990 & $\begin{array}{l}\text { Per capita production economic attitude or GDP to each } \\
\text { person - hour work }\end{array}$ \\
\hline Robbins $-21^{\text {st }}$ century & 2009 & $\begin{array}{l}\text { Changing inputs to outputs in the lowest level of costs and } \\
\text { achieving determined aims }\end{array}$ \\
\hline
\end{tabular}

One can say that productivity includes three elements: achieving the aims, how to use the resources efficiently and comparing the achieved product to what were possible (McKee, 2003). Therefore, in a managerial view, productivity shows the rate of system success in using resources to achieve the aims and relates to such concepts as deliverable, production, profitability, performance, production capacity, cost mitigation, extra work, quality, innovation, working life quality and culture and, in fact, is a combination of these concepts (Zahedi and Najjari, 2008). Noteworthy, productivity is divided into four levels: (1) HR productivity, (2) Organizational productivity, (3) Sectional productivity and (4) National productivity (Henry et al. 2006). In present study, the concept of HR productivity is analyzed.

\subsection{HR productivity}

Human resource is the main competitive advantage of any organization and that organization is more successful which enjoys more productive and capable human resources (Stewart and Brown, 2011, 4). Put it more correctly, the most valuable resource for any organizations is the knowledge, experience and skills of its manpower. Other resources of the organization will be used effectively by make this sensitive and important resource productive. In fact, organizations cannot achieve growth and development unless the productivity is improved and productivity is not improved unless manpower is productive (Goodarzi \& Attaei, 2009).

Human resources act as productivity improvement catalyst in organizations. Therefore, a proper strategy should be devised to improve productivity. Principally, the issue is that human is not comparable with other organizational factors. For instance, in a physical and industrial environment, the efficiency which the ratio of official capacity to existing capacity is never achieved to "one" while it can be greater than "one" for manpower which is an open system due to motivation, creativity, team working, right leadership and belief in justice establishment in the organization (Alvani \& Ahmadi, 2001).

\subsection{Affecting factors on HR productivity}

Identifying affecting factors on HR productivity is, inter alia, the main ideals of researchers in this field. All researchers believe that to improve HR productivity, one cannot provide only one factor. Rather, HR productivity should be considered as a combination of causes. Therefore, one should preliminarily identify and rank affecting factors and then should provide administrative guidelines (Mehrabian et al, 2011).

In his research on affecting factors on HR productivity in in industrial and agricultural cooperatives at Kermanshah, Farshadfar (2009) introduced training, discipline, management, 
motivation, proper payment system, consciousness and saving as the most important affecting factors on HR productivity. Alvani and Ahmadi (2001) investigated different models of affecting factors on HR productivity and introduced a comprehensive model which believes that 8 factors including motivational factors, leadership style, creativity and innovation, applied training and general training, competitiveness morale, demographical traits (marital status and age), job experience and physical and mental health are the factors that impact seriously on HR productivity. There are various models regarding affecting factors on HR productivity of which the most important ones are:

\subsection{CREST model}

In this model, factors in HR improvement are defined in the format of CREST. The main components of the model include (Hajj Karimi \& Pyrayesh, 2006): communication and commitment, respect, enthusiasm, security and support and training.

\subsection{Human resources productivity model}

Some authors have provided HR productivity model as below (Zahedi \& Najjari, 2008):

Will: it energizes, motivates and leads into decision making to perform or not to perform a job.

Can: it shows that how generated energy by "Will" is used rightly. It depends on capability, experience, specialized knowledge and spiritual/physical capability.

May: it paves proper grounds for using the generated energy. It depends on organizational and environmental factors such as work tools, resources, organizational structure, rules, etc.

Noteworthy, these three factors involve all internal and external facilities related to HR productivity. More such factors in an organization, more HR productivity and vice versa.

\subsubsection{Hersey and Goldsmith model}

This model introduced by Hersey and Goldsmith in 1980 planned to help managers to determine the reasons of productivity problems and to devise change strategies in order to resolve such problems (Sabokru et al, 2010). In their model (ACHIEVE), Hersey and Goldsmith identified seven variables that impact on individual's performance (P) and productivity:

Ability (A): the ability and power to perform a successful job.

Clarity $(\mathrm{C})$ : the clarity of tasks and how to perform them.

Help $(\mathrm{H})$ : factors including budget, sufficient human resources, equipment and facilities and any kind of help by organization.

Incentive (I): inner enthusiasm and propensity to do assignments without any reluctance.

Evaluation (E): assessment and the mechanism to understand the quality of performed actions.

Validity (V): justification and acceptance of HR related decisions.

Environment (E): adaptability with environment and other effective environmental factors 
such as competition, market situation, laws and supplier.

In other word: $\quad \mathrm{P}=\mathrm{f}(\mathrm{A}, \mathrm{C}, \mathrm{H}, \mathrm{I}, \mathrm{E}, \mathrm{V}, \mathrm{E})$

Noteworthy, used model in present study is seven - variable model of Hersey and Goldsmith.

\section{Research conceptual model}

According to conducted studies as well as research topic, research conceptual model (justice model by Greenberg and productivity model by Hersey and Goldsmith) is depicted in figure 1. According to research conceptual model, major and minor hypotheses of the research are provided as below.

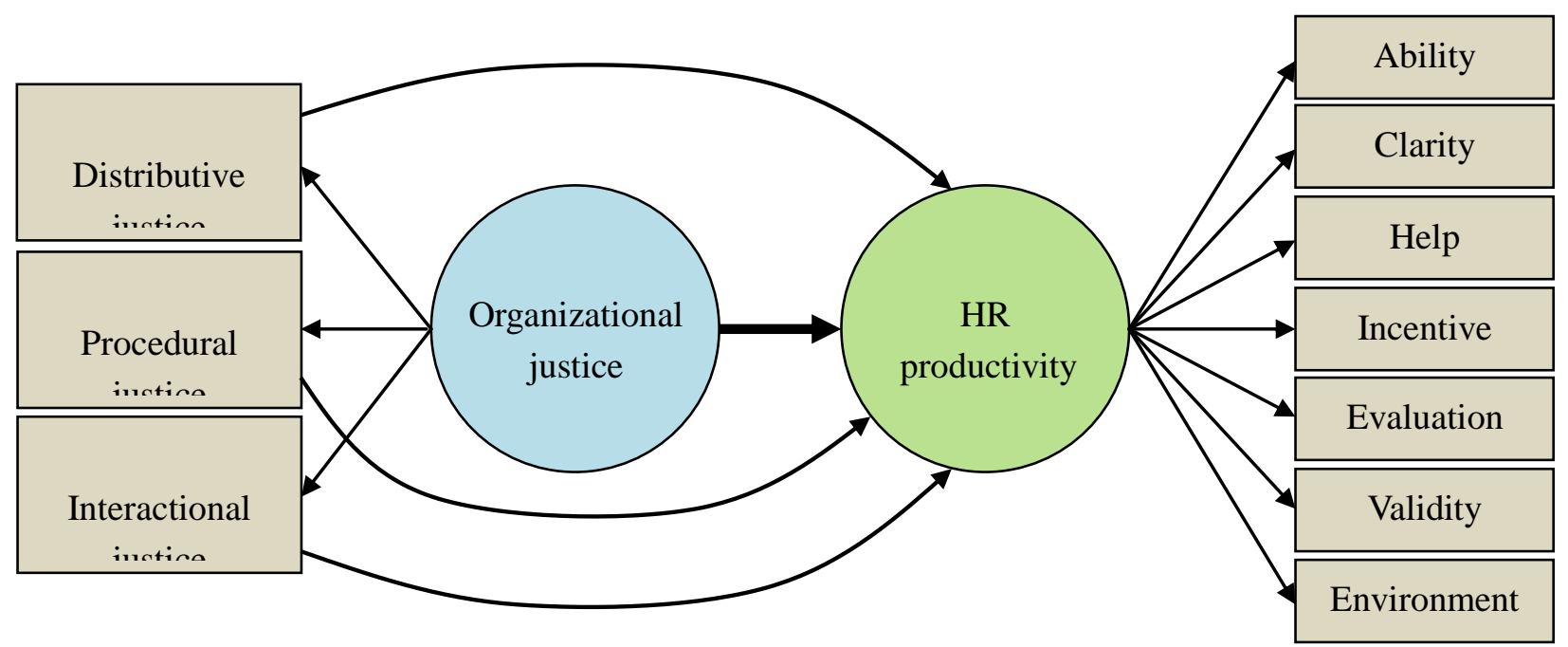

Figure 1: research conceptual model

\section{Hypotheses}

\subsection{Major hypothesis}

HR understanding of organizational justice impacts on their productivity.

\subsection{Minor hypotheses}

1. HR understanding of distributive justice impacts on their productivity.

2. HR understanding of procedural justice impacts on their productivity.

3. HR understanding of interactional justice impacts on their productivity.

\section{Methodology}

In terms of aim, this is an applied research and in terms of data collection, it is a descriptive (non-experimental) type survey. Its population consists of employees at all 8 boroughs of Qom Municipality, Central Municipality and Planning and Development Directorate of Qom Municipality $(n=220)$. By using ranked random sampling, the quantity of needed sample was 140. Since the author considered the possibility of failure in gathering some questionnaires, $30 \%$ was added to the sample volume. 


\section{Macrothink}

Finally, 141 analyzable and assessable questionnaires were collected.

$n=\frac{N Z_{\frac{\alpha}{2}}^{2} p q}{\varepsilon^{2}(N-1)+Z_{\frac{\alpha}{2}}^{2} p q}$

$$
n=\frac{220(1.96)^{2}(0.5)(0.5)}{(0.05)^{2}(219)+(1.96)^{2}(0.5)(0.5)} \approx 140
$$

Questionnaire is the main data collection tool. Totally, 26 questions for organizational justice and 21 questions for HR productivity were selected, that is, 47 questions were devised based on Likert five - scale range from 1 (very low) to 5 (very high). To determine the reliability of the questionnaire, 30 questionnaires were distributed and gathered in the statistical population. The Chronbach's alpha was 92.5. Likewise, to test its validity, the opinions of specialists, university professors and elites were used. In this stage, amendments were made through different interviews so it was assured that the questionnaire enjoy the same characteristic which authors seek.

Data analysis involves descriptive and inductive statistics. In table 2, descriptive statistics are outlined that involve gender, age and education.

Table 2: demographical status of the sample

\begin{tabular}{|c|c|c|c|}
\hline$\%$ & QTY & Variable & \\
\hline 80.9 & 114 & Male & \multirow{2}{*}{ Gender } \\
\hline 14.2 & 20 & Female & \\
\hline 1.4 & 2 & $>25$ & \multirow{4}{*}{ Age } \\
\hline 57.4 & 81 & $25-35$ & \\
\hline 27.7 & 39 & $35-45$ & \\
\hline 7.1 & 10 & $<45$ & \\
\hline 5 & 7 & Under diploma & \multirow{4}{*}{ Education } \\
\hline 31.9 & 45 & $\begin{array}{l}\text { Diploma and associate } \\
\text { of arts }\end{array}$ & \\
\hline 53.2 & 75 & B. A. & \\
\hline 3.5 & 5 & M.A. \& Ph. D & \\
\hline
\end{tabular}




\section{Macrothink}

\section{Research findings}

As seen in table 3, distributive variable with 3.74 average and standard deviation of 0.79 is in ideal status. Procedural justice in this organization is 2.23 in average and standard deviation of 0.61 is not in desired status. Interactional justice in this organization is 3.09 in average and standard deviation of 0.94 is not in desired status.

Table 3: the average status and standard deviation of variables

\begin{tabular}{|l|l|l|}
\hline & Average & Standard deviation \\
\hline Distributive justice & 3.74 & 0.79 \\
\hline Procedural justice & 2.23 & 0.61 \\
\hline Interactional justice & 3.09 & 0.94 \\
\hline
\end{tabular}

To indicate the relationship between two variables, one can use correlation and regression. In correlation, the relationship is two - way and the author do not know which variable impacts on other variable. If the authors know the relationship, he/she will use. Based on provided hypotheses (extracted from literature), it is obvious that the proper analysis to respond hypotheses correctly or incorrectly is regression analysis.

\subsection{Durbin - Watson test}

A hypothesis considered in regression is the independence of errors (difference between real and predetermined figures by regression equation). If this hypothesis is refused and errors are correlated, it will not be possible to use regression. Durbin - Watson test is used to study errors independence.

If correlation between errors is shown by ${ }^{\rho}$, then the statistic of DW test will be computed by

below equation: $\quad D W=2(1-\rho)$

Necessarily, the figure of this statistic is in $0-40$ intervals.

SPSS software is used to conduct DW test and the rate of DW statistic is computed 1.732 depicted in table 3 . Therefore, $\mathrm{H}_{0}$ (no correlation between errors) is supported or in corrector word, the hypothesis on no correlation between errors $(\rho=0)$ is not refused. So, one can use regression. In table 3, correlation coefficient, determination ratio, mitigated determination ratio, estimation standard deviation and the rate of DW statistic on productivity dependent variable as well as three independent variables namely distributive justice, interactional justice and procedural justice are computed and outlined. 


\section{Macrothink}

Table 4: correlation coefficients and DW statistic

\begin{tabular}{|l|l|l|l|l|l|}
\hline Model & $\begin{array}{l}\text { Multiple } \\
\text { correlation } \\
\text { coefficient (R) }\end{array}$ & R Square & Adjusted R Square & $\begin{array}{l}\text { Std. Error of the } \\
\text { Estimate }\end{array}$ & Durbin- \\
Watson
\end{tabular}

7.2. Regression variance analysis

Regression variance analysis is now used to investigate the existence/nonexistence of linear or nonlinear relationship between independent variable and dependent ones. According to table 4, one can say that if significance level (sig) is less than 5\%, linear model hypothesis will be confirmed.

Table 4: (ANOVA)

\begin{tabular}{|l|l|l|l|l|l|l|}
\hline \multicolumn{2}{|l|}{ Model } & $\begin{array}{l}\text { Sum of } \\
\text { Squares }\end{array}$ & df & $\begin{array}{l}\text { Mean } \\
\text { Square }\end{array}$ & F & Sig. \\
\hline \multirow{3}{*}{2} & Regression & 14.952 & 3 & 4.984 & 23.638 & 0.000 \\
\cline { 2 - 8 } & Residual & 28.885 & 137 & 0.211 & & \\
\cline { 2 - 8 } & Total & 43.837 & 140 & & & \\
\hline
\end{tabular}

Now, by considering the result of DW test and the possibility of using regression and model linearity, multiple regressions are used to estimate the model.

\subsection{Multiple regression}

By model estimation, table 5 is drawn through below regression equation.

$\hat{\mathrm{y}}=1.839+0.387 x_{1}+0.198 x_{2}+0.094 x_{3}$ 


\section{$\triangle$ Macrothink}

Table 5: regression ratios and significance levels

\begin{tabular}{|l|l|l|l|l|l|l|}
\hline \multicolumn{2}{|c|}{ Model } & \multicolumn{2}{|l|}{$\begin{array}{l}\text { Unstandardized } \\
\text { Coefficients }\end{array}$} & $\begin{array}{l}\text { Standardized } \\
\text { Coefficients }\end{array}$ & t & Sig \\
\cline { 2 - 7 } & B & Std. Error & Beta & 11.223 & 0.000 \\
\hline \multirow{2}{*}{3} & (Constant) & 1.839 & 0.164 & & 4.830 & 0.000 \\
\cline { 2 - 7 } & Distributive & 0.387 & 0.080 & 0.425 & 4.323 & 0.000 \\
\cline { 2 - 7 } & Interactional & 0.198 & 0.046 & 0.336 & 1.394 & 0.165 \\
\cline { 2 - 7 } & Procedural & 0.094 & 0.060 & 0.120 & \\
\hline
\end{tabular}

$\beta$ which is the standardized ratios indicate that the extent of changes in dependent variables is similar to changes in one standard deviation in independent variable. Greater abstract value means stronger relationship between independent and dependent variables.

Since in present model, the significance level of equality test for regression ratios and constant rate with 0 is less than $5 \%$ for distributive justice and interactional justice, the equality hypothesis of regression ratios and constant rate with 0 is refused and these two variables and constant rate are not exited from the equation. Thus, they impact on independent variable. Concerning procedural justice, since the significance level is 0.169 and greater than $5 \%$, it is exited from the equation and this equation will change to:

$\hat{y}=1.839+0.387 x_{1}+0.198 x_{2}$

To compare the impacts of two remained variables in regression model on dependent variable, only standardized ratios are used. $\beta$ Column indicates that distributive justice has the highest impact and one unit change in this variable would lead into 0.425 units of change in HR productivity. Likewise, one unit change in interactional independent variable would lead into 0.336 units of change in HR productivity.

\section{Discussion and conclusion}

The present study aims at investigating the impact of HR conception toward organizational justice on their productivity based on the defined aspects. The major hypothesis is that HR conception toward organizational justice on their productivity. 0.584 multiple correlation coefficient shows a positive relationship between organizational justice and HR productivity that confirms the results from this hypothesis. The findings of a study by Barati et al. (2009) indicate that organizational justice relates to employees' job performance positively. Studies by international authors (Boswell \& Boudreau, 2000; Cohen-Charash \& Spector, 2001; Robinson, 2004; Aryee et al., 2004) also indicate the achieved findings in present study and they have introduced organizational justice as a productivity and performance predictor. 
The first minor hypothesis reads that HR conception toward distributive justice impacts on their productivity. The findings of present study support this hypothesis and indicate that the conception of employees in 8 boroughs of Qom Municipality impacts their productivity. The influence ratio of conception toward distributive justice on HR productivity is 0.387 based on regression model which shows direct impact of distributive justice on human resources. Achieved $\beta$ for distributive justice is 0.425 . Such ramification is in line with a study by Haghighi et al (2009). They found that distributive justice impacts directly on employees' performance. They also said that $\beta$ is 0.33 which shows $33 \%$ changes in distributive justice dependent variable.

In this line, Boswell and Boudreau (2000) indicated that there is significant relationship between distributive justice and job performance. In the meantime, this result is not in line with studies by Tyler and Lind (1988) and Kim and Mauborgne (1993) since they didn't find any relation between distributive justice and performance. Differences between these findings and international results show can be due to various reasons. On reason is the cultural difference between population of this study and similar studies in Iran and populations at international studies. In developed countries, more emphasis is on secondary needs (belonging, respect, competition, etc.) since preliminary needs (food, cloth, house, sexual needs, etc.) are satisfied. In non-developed nations, on the other hand, such needs are not met and most people are thinking about them. On this basis, since individuals' preliminary needs are not yet satisfied in our society sufficiently, people are highly sensitive to their salaries and benefits; so, their conception toward distributive justice impacts on their performance. Another reason is that most studies on organizational justice and employees' performance are conducted in big private companies while this research is conducted in a public sector company. The study by Barati et al (2009) in Isfahan Steel Mill indicates that there is no relationship between distributive justice and performance and further researches are necessary.

The second minor hypothesis reads that HR conception toward procedural justice impacts on their productivity. The findings of regression analysis as well as regression model show that this hypothesis is no supported. In present study, procedural justice has no remarkable impact on employees' productivity to which the most important reason can be the administrative role of studied organization and organizational procedures posed by monitoring agencies that have led into undesired situation of procedural justice. Therefore, employees' productivity is more impacted by other variables rather than procedural justice and one can say that procedural justice in this organization plays the role of a motivator in two health and motivation factors so that in contrary to expectations, the undesired situation of procedural justice does not lead into productivity mitigation and based on thematic and field evidences, procedural justice improves productivity. The study by Barati et al (2009) proves the relationship between procedural justice and performance only in associate of arts group and there is no relationship between procedural justice and performance in other educational groups. It confirms the results of this study that its population with different educational groups most of which are not associate of arts group (over 70\%). However, by using social exchange theory, some authors (Masterson et al., 2000; Cropanzano \& Prehar, 1999) believe that job performance relates to both leadership and organizational levels. So, they believe that job performance is 
partly impacted by relations between staff and organization (which relates to procedural justice) and partly by relations between employees and immediate supervisors (which relates to interactional justice). On this basis, many writers (Tyler \& Lind, 1988; Greenberg, 1987; Brockner \& Wiesenfeld, 1996; Kim \& Mauborgne, 1993; Boswell \& Boudreau, 2000) conducted studies on the impact of procedural justice on employees' performance and concluded that employees' conception toward procedural justice impacts on their performance positively. It means that when employees believe that organizational procedures are fair, they attempt to perform their task better. Such ramification is in line with a study by Haghighi et al (2009) on the impact of procedural justice on employees' performance as well as with international studies. Their findings indicate that there is a positive relationship between procedural justice and employees' performance.

The third minor hypothesis reads that HR conception toward interactional justice impacts on their productivity. The findings of linear regression final model support this hypothesis. The influence ratio of conception toward interactional justice on HR productivity is 0.198 based on regression model which shows direct impact by interactional justice on HR productivity. Achieve $\beta$ ratio for interactional justice is 0.336 . In one hand, interactional justice literature indicates that people are sensitive based on the quality of treatment with them in mutual personal relations as well as structural aspects of decision making process. As a result, if they think that their immediate supervisor is treating them unfairly, they may react negatively (Rezaeeian, 2005, 5) which is adaptive to the results of present study.

On the other hand, the results of a research by Haghighi et al (2009) which are similar to the results of international studies (Tyler \& Lind, 1988; Brockner \& Wiesenfeld, 1996; Kim \& Mauborgne, 1993) indicate employees' conception on interactional justice does not relate to their performance significantly. It means that employees' conception on interactional justice does not decrease or increase their performance.

\section{References:}

1. Abu Elanain, H. M. (2010). Testing the direct and indirect relationship between organizational justice and work outcomes in a non-Western context of the UAE. Journal of Management Development, 29(1), 5-27.

2. Alvani, S. M., \& Ahmadi, P. (2001). Designing a comprehensive management pattern concerning affecting factors on HR productivity. Bahar, 5(1), 1-20.

3. Ambrose, M., Hess, R. L., \& Ganesan, S. (2007). The Relationship between Justice and Attitudes, An Examination of Justice Effects on Event and System-Related Attitudes. Organizational Behavior and Human Decision Processes, 103(1), 21-36.

4. Aryee, S., Chen, Z., Budhwar, P. (2004). Exchange Fairness and Employee Performance: an Examination of the Relationship between Organizational Politics and Procedural Justice. Organizational Behavior and Human Decision Processes, 94 (1), $1-14$.

5. Asian Productivity Organization. (2009). APO Productivity DataBook. Tokyo, Keio 
University Press Inc.

6. Barati, H., Arizi, H. R., \& Noory, A. (2009). The simple and multiple relationships of organizational justice and job performance in Isfahan Steel Mill. Management Outlook, 33, 9-28.

7. Barclay, L. J. (2005). Following in the footsteps of Mary Parker Follett: Exploring how insights from the past can advance organizational justice theory and research. Management Decision, 43(5), 740-760.

8. Bos, Kees van den (2002). Assimilation and contrast in organizational justice: The role of primed mindsets in the psychology of the fair process effect. Organizational Behavior and Human Decision Processes, 89(1), 866-880.

9. Boswell, W. R., \& Boudreau, J. W. (2000). Employee Satisfaction with Performance Appraisals and Appraisers: The Role of Perceived Appraisal Use. Human Resource Development Quarterly, 11, 283-300.

10. Brockner, J., \& Wiesenfeld, B. M. (1996). An integrative framework for explaining reactions to decisions: Interactive effects of outcomes and procedures. Psychological Bulletin, 120(2), 189-208.

11. Cohen-Charash Y., \& Spector, P. E. (2001). The role of justice in organizations: A meta-Analysis. Organizational Behavior and human decision processes, 86(2), 278-321.

12. Colquitt, J. A., Scott, B. A., Judge, T. A., \& Shaw, J. C. (2006). Justice and personality: Using integrative theories to derive moderators of justice effects. Organizational Behavior \& Human Decision Processes, 100(1), 110-127.

13. Cremer, D. D. (2005). Procedural and distributive justice effects moderated by organizational identification. Journal of Managerial Psychology, 20(1), 4-13.

14. Cropanzano, R., \& Prehar, C. A. (1999). Using social exchange theory to distinguish procedure from interactional justice. Paper presented at the annual meeting of the society for industrial and organizational psychology, Atlanta: ga.

15. Dulebohn, J. H., Conlon, D. E., Sarinopoulos, I., Davison, R. B., \& McNamara, G. (2009). The biological bases of unfairness: Neuroimaging evidence for the distinctiveness of procedural and distributive justice. Organizational Behavior and Human Decision Processes, 110, 140-151.

16. Eberlin, R. J., \& Tatum, B. C. (2005). Organizational justice and decision making when good intentions are not enough. Management Decision, 43(7/8), 1040-1048.

17. Eberlin, R. J., \& Tatum, B. C. (2008). Making just decisions: organizational justice, decision making, and leadership. Management Decision, 46(2), 310-329.

18. Farshadfar, Z. (2009). Affecting factors on HR productivity in Industrial and agricultural cooperatives at Kermanshah. Cooperation, 20(202-203), 35-48.

19. Greenberg, J. (1987). A Taxonomy of Organizational Justice theory. Academy of 
management Review, 12(1), 9-22.

20. Gudarzi, M., \& Attaei, M. (2009). The relationship between salary and HR productivity in university. Organizational/Industrial Psychology News, 1(1), 71-76.

21. Honary, H., Rezaeeian, A., Kuzehchian, H., \& Ehsani, M. (2006). Movement, 27, 45-54.

22. Haghighi, M., Ahmadi, I., \& Raminmehr, H. (2009). Studying the impact of organizational justice on employees' performance. Organizational Culture Management, 20(7), 70-101.

23. Hajj Karimi, A., \& Pyrayesh, R. (2006). Clarifying affecting factors on HR productivity in public organizations by using path analysis technique. Management Culture, 14(4), 57-86.

24. Hassan, A., \& Hashim, J. (2011). Role of organizational justice in determining work outcomes of national and expatriate academic staff in Malaysia. International Journal of Commerce and Management, 21(1), 82-93.

25. Hersey, P., \& Goldsmith M. (1980). A Situational Approach to Performance Planning. Training \& Development Journal, 34(11), 38-44.

26. Hoy, W. K., \& Tarter, C. J. (2004). Organizational justice in schools: no justice without trust. International Journal of Educational Management, 18(4), 250-259.

27. Jafari, P., Shafiepour Motlagh, F., \& Yarmohammadian, M. H. (2011). Designing an adjusted model of organizational justice for educational system in Esfahan City (Iran). Procedia Social and Behavioral Sciences, 15, 1696-1704.

28. Jawahar, I. M.(2002). A Model of Organizational Justice and Workplace Aggression. Journal of Management, 28(6), 811-834.

29. Johnson, R. E., Selenta, C., \& Lord, R. G. (2006). When organizational justice and the self-concept meet: Consequences for the organization and its members. Organizational Behavior and Human Decision Processes, 99, 175-201.

30. Kim, W., \& Mauborgne, R. A. (1993). Procedural Justice, Attitudes, and Subsidiary Top Management Compliance with Multinationals' Corporate Strategic Decisions. Academy Of Management Journal, 36(3), 502-526.

31. Layeghi, S. (2011). Studying the relationship between employees' empowerment and HR productivity in Urbanism Ministry Headquarters, Tehran, University of Tehran.

32. Masterson, S. S., Lewis, K., Goldman, B. M., \& Taylor, M. (2000). Integrating Justice and Social Exchange: The Differing Effects of Fair Procedures and Treatment on Work Relationships. Academy Of Management Journal, 43(4), 738-748.

33. McCain, S., Tsai, H., \& Bellino, N. (2010). Organizational justice, employees' ethical behavior, and job satisfaction in the casino industry. International Journal of Contemporary Hospitality Management, 22(7), 992-1009.

34. McDowall, A., \& Fletcher, C. (2004). Employee development: an organizational 
justice perspective. Personnel Review, 33(1), 8-29.

35. McKee, D. (2003). Productivity tools: horses for courses. Work Study, 52(3), 136-140.

36. Mehrabian, F., Nasirypor, A., \& Keshavarz Mohammadian, S. (2011). Studying the importance of identified variables of HR productivity in the view of Gilan Medical Universities' employees and faculties, Scientific and Research Journal of Zanjan Medical University, 75(19), 94-106.

37. Mohammdi, M., \& Nooryfard, M. (2008). The impact of innovation and creativity on improving HR productivity, Setabran, 52, 88-91.

38. Nabatchi, T., Bingham, L., \& Good, D. H. (2007). Organizational justice and workplace mediation: a six-factor model. International Journal of Conflict Management, 18(2), 148-174.

39. Nirmala, M. C., \& Akhilesh, K. B. (2006). An attempt to redefine organizational justice: in the rightsizing environment. Journal of Organizational Change Management, 19(2), 136-153.

40. Olkkonen, M., \& Lipponen, J. (2006). Relationships between organizational justice, identification with organization and work unit, and group-related outcomes. Organizational Behavior and Human Decision Processes, 100, 202-215.

41. Rezaeeian, A. (2005). Justice expectation and justice in organization, Tehran, SAMT Publications.

42. Robinson, K. (2004). The Impact of Individual Differences on the Relationship between Employee Perceptions of Organizational Justice and Organizational outcome Variables. PhD Dissertation, Alliant International University, San Diego, CA.

43. Sabokru, M., Vafaei Yeganeh, M., \& Kashani, S. (2010). HR productivity in insurance companies in terms of emotional intelligence and working life style. Insurance Industry Quarterly, 25(1), 179-201.

44. Sharifzadeh, F., \& Mohammadi Moghadam, Y, (2009). The relationship between employees' empowerment and HR productivity of Lorestan Law Enforcement forces. Law Enforcement Management Studies Quarterly, 4(1), 5-18.

45. Stewart, G. L., \& Kenneth G. B. (2011). Human Resource Management: Linking Strategy to Practice (Second Edition), Wiley.

46. Till, R. E. \& Karren, R. (2011). Organizational justice perceptions and pay level satisfaction. Journal of Managerial Psychology, 26(1), 42-57.

47. Tyler, T. R., \& Lind, E. A. (1988). The social psychology of procedural justice. Newyork: plenum press.

48. Wang, X., Liao, J., Xia, D., \& Chang, T. (2010). The impact of organizational justice on work performance: Mediating effects of organizational commitment and leader-member exchange. International Journal of Manpower, 31(6), 660-677.

49. Yilmaz, K., \& Tasdan, M. (2009). Organizational citizenship and organizational 
justice in Turkish primary schools. Journal of Educational Administration, 47(1), 108-126.

50. Zahedi, S., \& Najjari, R. (2008). HR productivity and knowledge management, Peyk-e-Noor, 6(1), 2-13.

51. Zapata-Phelan, C. P., Colquitt, J. A., Scott, B. A., \& Livingston, B. (2009). Procedural justice, interactional justice, and task performance: The mediating role of intrinsic motivation. Organizational Behavior and Human Decision Processes, 108, 93-105. 